\title{
Epilogue: Some Reflections
}

Since I have offered conclusions on each topic discussed in the individual chapters of the book, I would like to end by offering the reader some general reflections on the status of women in ancient Judaism. The writings of that period have had a great impact on the status of women in contemporary Western society, despite the fact that they did not represent the real circumstances with complete fidelity. There is always a distinction between what ought to be and what is - the writings do not represent the actual facts of life, though they nevertheless had a practical effect, if not to the extent of becoming fully realized - but this truth does not neutralize the effect of writings deemed to be decreed by God, duly interpreted, and thus holy and mandatory. The nevertheless incomplete fulfillment of the rules thus conveyed is due to a number of factors that explain this baffling and unexpected reality. The first is the deeply entrenched anthropological disposition to reject that which is imposed by authority, the instinctive opposition to any restriction of an idealized boundless freedom to do as one pleases, and, last but not least, the temptation to do what is forbidden and the pleasure derived from rebellion in itself. Ancient philosophers and thinkers were already aware of the potential allure of this innate human urge, as we observe in Prov 9:17: מים גנובים ימתקו ולחם סתרים ינעם "Stolen water is sweet; food eaten in secret ${ }^{1}$ is delicious," and they warned against the dangers of succumbing to it. The second significant factor lies in the different interpretations of rules assumed to be divine, creating distinct ordinances in different societies or in different groups within the same society; they may range from doctrinal or ritual issues that seem minor from a modern perspective but were deemed of great significance at the time, up to the most crucial concerns, leading to unbridgeable chasms and decisive splits; yet all these questions alluded to the same primary scriptural source, equally revered by all parties. The disagreements between the Pharisees and the Sadducees about the interpretation of Scripture did not provoke a split such as occurred between the Pharisees and the Essenes/Qumran, although all these conflicts turned on the issue of whose interpretation of the same source was correct. It is not easy, in part because of the lack of any authentic Sadducean writings, to determine whether the conflicts between the Essenes and the Pharisees were of greater importance than those between the Pharisees and the Sadducees, circumstances that would explain the different practical consequences of the

1 A metaphoric axiom referring to evil deeds (fornication, according to some traditional commentators), usually performed in secret.

(C) PAUl HEgER, 2014 | DOI 10.1163/9789004277113_011

This is an open access chapter distributed under the terms of the Creative Commons

Attribution-Noncommercial 3.o Unported (CC-BY-NC 3.o) License. 
ideological dissensions. Nevertheless, I would hypothesize that other factors also influenced the different reaction of the Essene community; one may envisage that they were more zealous in their adherence to the simple meaning of the text, accusing their opponents of adulterating the biblical text through reprehensible interpretive methods. The practical differences between the halakhot of the Essenes and the Pharisees were not of greater significance than those between the Pharisees and the Sadducees, but it was their dissimilar attitudes towards the meticulous and correct fulfillment of biblical decrees which lay at the root of their different reactions. We can also not exclude that personal rivalries between the respective leaders, and the extreme loyalty and devotion of the Qumran community to their revered leader — as we may glean from their writings - bolstered the escalation of enmity between the two groups, provoking the creation of further peculiar dogmas which in turn led to a final schism. The split between Judaism and Christianity, however, was motivated by much more significant interpretational differences, albeit concerning the identical holy writ of the Old Testament. It is not within the scope of this book to elaborate on this topic, despite its supreme significance for Western culture; the comparison is offered simply as an example of the varying extent of differences that can result from divergent interpretations of the identical primary source.

One of the book's key tasks has been to analyse differences among interpretations of relevant biblical texts regarding the character of women, along with their practical ramifications. We do not possess an authoritative primeval interpretation of the Creation and Fall narratives, which would be a crucial primary source for the establishment of attitudes from a variety of perspectives towards women. I have brought maximum intellectual rigour to the task of detaching myself from the common interpretations of these narratives in Judaeo-Christian culture, in order to present an objective interpretation as the basis for comparison with the Qumranic and rabbinic interpretations. My hope in doing so is to proffer a reasonable assumption of each group's interpretation of the relevant biblical texts, despite the lack of elaborate interpretations of the biblical texts and halakhot relating to women in Qumran writings, comparable to rabbinic literature. Guided also by my conviction, based on my comparative studies of Qumranic and rabbinic interpretational methods, that Qumran adhered to a straightforward interpretation of Scripture, I believe I have demonstrated this method at work in relation to Qumran's attitude towards women, as deduced from examination of the relevant Qumranic writings. Women were not members of the exclusive Yahad group, nor were they obligated to fulfill all biblical precepts as the men were, and they lacked any independent legal status in marriage; on the other hand, they are not accused 
in Qumran of the instigation of the Fall, and their character is not sullied as agents of temptation, engendering evil behaviour in men. In this, Qumran follows an objective, unbiased interpretation of Gen 1-3, similar to the basis of my own interpretation. The rabbis, on the other hand, interpreting the identical texts that both groups believed to be the most holy and mandating divine utterances, reached different results. In my opinion, this was due to their preconceived attitude towards women: as pragmatists they considered the realities of life in their period, and the prospects for their halakhic decisions to be acknowledged and practised by the people. Accordingly, their approach was to interpret the relevant biblical texts and rules according to the circumstances of the time and their own thought processes. They believed that the Israelite nation's learned spiritual leadership had the competence and authority to interpret the divine will and intention, adapting it to current circumstances and asserting that their halakhic decisions corresponded to God's omniscient intention in light of such circumstances.

We have observed how the different interpretive methods of Qumran and the rabbis affected their respective attitudes towards women. In contrast to Qumran, the rabbis offer us a clearly negative portrayal of women, deduced through their midrashic interpretive method from the identical texts. The rabbinic attitude towards women may have been influenced by prejudicial Greek conceptions about women, but in the end the rabbis claimed their viewpoint to be derived from Scripture. By the same token we encounter rabbinic midrashim that glorify the importance of women for the husband and the family, in apparent contradiction to those midrashim which emphasize their allegedly wicked and dangerous character. I have attempted to reconcile these two seemingly conflicting perceptions by discerning the distinct aspects of the two topics. Woman was created by God for the purpose of being a helper and companion to the man, and hence she is to be praised for fulfilling her divinely ordained function. On the other hand, her God-given desire for men makes her a source of danger to men's ethical behaviour, due to her physical fascination. Pragmatically, the rabbis distrusted men's ability to resist stumbling into sin, and therefore imposed the onus of ensuring society's ethical behaviour on women. Qumran, in contrast, did not accept the frailty of men's nature as a reason to concede them indulgence, but insisted that their members must be able to resist women's attractiveness; they did not consider practical circumstances in their halakhic decisions in this case, as they did in other situations.

We may thus see how interpretive systems affect the outcome of doctrinal and practical (halakhic) topics. I have devoted much attention to the interpretation of the Creation and Fall narratives, since such interpretation established the background of the halakhic ramifications of the status of women, their 
rights and obligations. While I am aware that the respective circumstances had an impact on both the compilation of the biblical narratives and their later interpretations - that is, they were in part aetiological formulations - we must recognize that both the compilers of the Torah and its later commentators and interpreters did not compose and redact their writings to reflect without qualification the current circumstances, intending to justify those circumstances as ordained from heaven. Judaism, from its inception, absorbed narratives and rules from the surrounding cultures, but adapted these to particular Israelite beliefs and viewpoints about right and wrong in the course of their incorporation in Israelite lore and civilization. Here too, as it seems to me, we must consider that both Qumran and the rabbis were aware of human inclinations and shortcomings, as well as the influence of the surrounding societies and cultures that in part created the prevailing circumstances; they did not by any means accept this influence wholesale, but rather attempted to eradicate or to modify it through their rules and homilies, each group in its own manner and to its own extent, according to its particular theology.

These reflections have constituted the guiding principles of my research on the status of women in different periods and segments of Israelite society and on the ramifications of the Creation and Fall narratives on the practical and legal aspects of the problem. Finally, I would like to add that although I have tried to substantiate my vision of this topic by the citation of supporting quotations, scholarly opinions, and logical considerations, I have never considered my conclusions to be the one and only truth; I have followed one mode among many of reading the primary texts. While I may believe that my arguments, supporting evidence, and logic are more convincing than those offered by other scholars, I remain aware that others may perceive things differently; it behooves the readers to decide his or her own preference. 